FACTA UNIVERSITATIS

Series: Physical Education and Sport, Vol. 18, No 3, 2020, pp. 553 - 557

https://doi.org/10.22190/FUPES181010053T

Narrative review article

\title{
SPORTS AND EXERCISE MEDICINE IN THE COVID-19 ERA - LET'S MAKE IT A GOOD MARATHON RUN
}

\author{
UDC 61: 796/799 \\ $61($ COVID-19)
}

\begin{abstract}
Milena Tomović
Faculty of Physical Education and Sport Sciences, Aristotle University of Thessaloniki,

Thessaloniki, Greece
\end{abstract}

\begin{abstract}
The aim of this short narrative review is to investigate the role of sports and exercise medicine (SEM) in managing the current and future pandemics. The coronavirus outbreak caught the whole world by surprise and very quickly imposed the long run ahead of us, changing every aspect of modern living. Being primarily a health crisis, the COVID-19 pandemic placed the biggest strain on the medical community and science. Our understanding of the new circumstances is constantly being updated with new scientific data and medical and other professions directly dealing with the pandemic has to provide the best available (evidence-based) approach. SEM expertise has a huge impact on population's general health and its role in dealing with COVID19 and future pandemics has to be recognised in several aspects. The multidisciplinary, prevention-orientated, and structured approach of SEM can be crucial for healthoriented community changes.
\end{abstract}

Key words: COVID-19, Physical Activity, Health, Prevention

\section{INTRODUCTION}

The coronavirus outbreak caught the whole world by surprise and very quickly imposed the long run ahead of us, changing every aspect of modern living. Being primarily a health crisis, the COVID-19 pandemic placed the biggest strain on the medical community and science. It is now clear that COVID-19 is here to stay and that prevention is the only effective measure we can take until an efficient and safe vaccine is ready. Like in every major crisis, dealing with it creates new opportunities for society to develop, evolve and educate (Hughes et al., 2020).

Received October 10, 2018/ Accepted December 01, 2020

Corresponding author: Milena Tomović

Faculty of Physical Education and Sport Sciences, Aristotle University of Thessaloniki,

Aristotle University of Thessaloniki, 54124 Thessaloniki, Greece

Phone: + $302310991871 \cdot$ E-mail: milenatomovic83@gmail.com

두 2020 by University of Niš, Serbia | Creative Commons License: CC BY-NC-ND 
The aim of this short narrative review is to investigate the role of sports and exercise medicine (SEM) in managing the current and future pandemics.

\section{THEORETICAL CONSIDERATIONS OF THE PROBLEM}

COVID-19 is a multi-organ disease that can affect the lungs, heart, kidneys, nervous system, liver etc. (Zaim, Chong, Sankaranarayanan, \& Harky, 2020). The important aspect of COVID-19 is that in some cases (about $10 \%$ of patients tested positive for SARS-CoV-2 virus) the results in chronic presentation are also known as post-acute or long COVID. The prolonged form of the disease requires adequate evaluation and a close follow-up. The most common symptoms are a cough, low grade fever, and fatigue, followed by shortness of breath, muscle pain and weakness, chest pain and, headaches. A recent study on long COVID-19 acknowledged the importance of gradual return to physical activity (PA) and work using a general population, structured and individualized rehabilitation program - four to six weeks of light aerobic exercise (Barker-Davies et al., 2020; Greenhalgh, Knight, A'Court, Buxton, \& Husain, 2020). Cardiac involvement and eventual deficit can be common in previously hospitalized patients according to a JAMA study and its cardiovascular magnetic resonance (CMR) findings (Puntmann et al., 2020). In a cohort of elite athletes post COVID-19 myocardial inflammation (CMR confirmed) was present even in some asymptomatic COVID-19 positive athletes (Rajpal et al., 2020). These findings suggest that adequate health pre-participation evaluation (PPE) of physically active individuals must be warranted (Wilson et al., 2020).

The scope of a pre-participation clinical exam is not easy to determine especially in times when health systems of individual countries are under the burden of a pandemic. At the same time, pandemic-induced lower PA levels among the general population and any unjustified post-PPE restriction of PA could be detrimental to individual and population health (World Health Organization, 2020). SEM professionals should be able to apply their expertise in an individual, structured and gradual approach when evaluating and preparing athletes and other physically active individuals for return to the field of sports and exercise. Special concern should be made for those with persistent symptoms, severe clinical presentation and those involved in high intensity work and exercise load. According to the recently published European Cardiology Association Guideline on Sports Cardiology and Exercise in Patients with Cardiovascular Disease, return to sport participation should be a joint decision of the athlete/patient and attending physician (Pelliccia et al., 2020).

SEM needs to adapt its practices to limited recourses and preventive measures - risk stratification, daily monitoring of elite athletes, remote assessment and field testing are valuable tools and should be developed further (Freeman \& Eykelbosh, 2020; Dijkstra et al., 2020). It is important for the challenge of COVID-19-induced regular follow up and health evaluation of athletes and other physically active individuals to be managed in a scientifically sound manner. Available International Olympic Committee guidelines on reporting epidemiological data on injury and illness in sport (Bahr et al., 2020) may provide a uniform approach and future data comparison.

As stated earlier, prevention is key for the current fight against COVID-19. In sport settings, SEM professionals are the most responsible for epidemiological measures and virus transmission control. Their expertise in injury and illness prevention programs should allow good understanding of the present situation (Bahr \& Krosshaug, 2005; 
Jacobsson \& Timpka, 2015; Drew et al., 2017). The same methods of continuous education, quality control and structured programs should be applied and scientifically evaluated (Bizzini \& Dvorak, 2015). The recently published Infectious Diseases Outbreak Management Tool for endurance of mass participation sporting events helps competition risk assessment and encourages the use of sports bodies' expertise with that of the local and regional public health system (Adami et al., 2020).

The SEM role in dealing with the COVID-19 crisis goes beyond virus transmission control. The COVID-19 clinical presentation of the patients previously diagnosed with some of the most common chronic non-communicable diseases tends to get more severe and more often requires hospitalisation and intensive care (World Health Organization, 2020). Regular PA can remove 6-10 \% of major chronic non-communicable diseases globally (Lee et al., 2012). SEM involvement in global health can be crucial for control of inevitable future pandemics. Physical fitness is a good predictor of general health and adjuvant treatment in many chronic conditions. Further development and promotion of structured and regular PA requires enrolment of appropriately trained SEM professionals (Armstrong, Brubaker, Otto, \& Whaley, 2005). Efforts should be made to develop structured and evidence-based educational programs for the field of SEM globally. Primary, secondary and tertiary prevention through regular PA can be of crucial interest for the future control of the world's health (World Health Organization, 2018).

Good control of the ongoing pandemic requires a multidisciplinary approach and team effort. SEM is a good example of several medical and sports disciplines working together. Additionally, application of advanced technologies for remote assessment and doping testing of professional athletes can be a valuable tool for the general population as well (Dijkstra et al., 2020; Pitsiladis, Muniz-Pardos, Miller, \& Verroken, 2020). Professional sport with its economic impact plays a significant role in improving community health. Media coverage of sporting events has a great potential for promotion of PA and healthy life habits (Mann, Clift, Boykoff, \& Bekker, 2020). New aspects of SEM expertise that emerged during the ongoing pandemic crisis should be scientifically evaluated and structured in consensus statements and relevant guidelines. Good examples are the recently published remote health assessment review and advanced methods for doping testing (Dijkstra et al., 2020; Pitsiladis et al., 2020). Furthermore, during the lockdown, an increasing number of individuals started structured exercise with sport patterns like walking, running, biking etc., making the role of a SEM expertise even more relevant for the COVID-19 crisis (Ding et al., 2020).

\section{CONCLUSION}

COVID-19 is here to stay and the fight against it very quickly evolved from fast solutions (lockdown) to a long distance, Ironmen run. Our understanding of the new circumstances is constantly being updated with new scientific data and medical and other professions directly dealing with the pandemic has to provide the best available (evidencebased) approach. SEM expertise has a huge impact on the population's general health and its role in dealing with COVID-19 and future pandemics has to be recognised in several aspects. The multidisciplinary, prevention-orientated, and structured approach of SEM can be crucial for healthoriented community changes. 


\section{REFERENCES}

Adami, P.E., Cianca, J., McCloskey, B., Derman, W., Steinacker, J.M., Connor, F., et al. (2020). Infectious diseases outbreak management tool for endurance mass participation sporting events: an international effort to counteract the COVID-19 spread in the endurance sport setting. British Journal of Sports Medicine, bjsports2020-103091. https://doi.org/10.1136/bjsports-2020-103091

Armstrong, L.E., Brubaker, P.H., Otto, R.M., \& Whaley, M.H. (2005). ACSMs New Preparticipation Health Screening Recommendations from ACSMs Guidelines for Exercise Testing and Prescription.

Bahr, R., \& Krosshaug, T. (2005). Understanding injury mechanisms: a key component of preventing injuries in sport. British Journal of Sports Medicine, 39(6), 324-329.

Bahr, R., Clarsen, B., Derman, W., Dvorak, J., Emery, C.A., Finch, C.F., et al. (2020). International Olympic Committee consensus statement: Methods for recording and reporting of epidemiological data on injury and illness in sports 2020 (including the STROBE extension for sports injury and illness surveillance (STROBESIIS)). Orthopaedic Journal of Sports Medicine, 8(2). https://doi.org/10.1177/2325967120902908

Barker-Davies, R.M., O’Sullivan, O., Senaratne, K.P.P., Baker, P., Cranley, M., Dharm-Datta, S., et al. (2020). The Stanford Hall consensus statement for post-COVID-19 rehabilitation. British Journal of Sports Medicine, 54(16), 949-959.

Bizzini, M., \& Dvorak, J. (2015). FIFA 11+: an effective programme to prevent football injuries in various player groups worldwide-a narrative review. British Journal of Sports Medicine, 49(9), 577-579.

Dijkstra, H.P., Ergen, E., Holtzhausen, L., Beasley, I., Alonso, J.M., Geertsema, L., et al. (2020). Remote assessment in sport and exercise medicine (SEM): a narrative review and teleSEM solutions for and beyond the COVID-19 pandemic. British Journal of Sports Medicine, 54(19), 1162 LP-1167.

Ding D., del Pozo Cruz B., Green M.A., \& Bauman A.E. (2020). Is the COVID-19 lockdown nudging people to be more active: a big data analysis. British Journal of Sports Medicine, 54, 1183-1184.

Drew, M., Nicole, V., David, H., Renee, A., Kirsten, P., Louise, B., et al. (2017). Stay healthy: an Australian Institute of Sport illness prevention project. British Journal of Sports Medicine, 51(4), 313.1-313. https://doi.org/10.1136/bjsports-2016-097372.76

Freeman, S., \& Eykelbosh, A. (2020). COVID-19 and outdoor safety: Considerations for use of outdoor recreational spaces. Vancouver: BC Centre for Disease Control, National Collaborating Centre for Environmental Health.

Greenhalgh, T., Knight, M., A'Court, C., Buxton, M., \& Husain, L. (2020). Management of post-acute covid-19 in primary care. The BMJ, 370. https://doi.org/10.1136/bmj.m3026

Hughes, D., Saw, R., Perera, N.K.P., Mooney, M., Wallett, A., Cooke, J., et al. (2020). The Australian Institute of Sport framework for rebooting sport in a COVID-19 environment. Journal of Science and Medicine in Sport, 23(7), 639-663.

Jacobsson, J., \& Timpka, T. (2015). Classification of prevention in sports medicine and epidemiology. Sports Medicine, 45(11), 1483-1487.

Lee, I.M., Shiroma, E.J., Lobelo, F., Puska, P., Blair, S.N., Katzmarzyk, P.T., et al. (2012). Effect of physical inactivity on major non-communicable diseases worldwide: An analysis of burden of disease and life expectancy. The Lancet, 380(9838), 219-229.

Mann, R.H., Clift, B.C., Boykoff, J., \& Bekker, S. (2020). Athletes as community; athletes in community: covid-19, sporting mega-events and athlete health protection. British Journal of Sports Medicine, 54(18), 1071 LP-1072.

Pelliccia, A., Sharma, S., Gati, S., Bäck, M., Börjesson, M., Caselli, S., et al. (2020). 2020 ESC Guidelines on sports cardiology and exercise in patients with cardiovascular disease. European Heart Journal, https://doi.org/10.1093/eurheartj/ehaa605

Pitsiladis, Y., Muniz-Pardos, B., Miller, M., \& Verroken, M. (2020). Sport integrity opportunities in the time of coronavirus. Sports Medicine, 50(10), 1701-1702.

Puntmann, V.O., Carerj, M.L., Wieters, I., Fahim, M., Arendt, C., Hoffmann, J., et al. (2020). Outcomes of Cardiovascular magnetic resonance imaging in patients recently recovered from coronavirus disease 2019 (COVID-19). JAMA Cardiology. https://doi.org/10.1001/jamacardio.2020.3557

Rajpal, S., Tong, M.S., Borchers, J., Zareba, K.M., Obarski, T.P., Simonetti, O.P., et al. (2020). Cardiovascular magnetic resonance findings in competitive athletes recovering from COVID-19 infection. JAMA Cardiology. https://doi.org/10.1001/jamacardio.2020.4916

Wilson, M.G., Hull, J.H., Rogers, J., Pollock, N., Dodd, M., Haines, J., et al. (2020). Cardiorespiratory considerations for return-to-play in elite athletes after COVID-19 infection: a practical guide for sport and exercise medicine physicians. British Journal of Sports Medicine, 54(19), 1157-1161.

World Health Organization. (2018). Global Action Plan on Physical Activity 2018-2030. Journal of Policy Modeling. 
World Health Organization. (2020). Clinical management of COVID-19: Interim guidance, 27 May 2020. World Health Organization.

World Health Organization \& United Nations Development Programme. (2020). Responding to noncommunicable diseases during and beyond the COVID-19 pandemic: state of the evidence on COVID-19 and non-communicable diseases: a rapid review. World Health.

Zaim, S., Chong, J.H., Sankaranarayanan, V., \& Harky, A. (2020). COVID-19 and multiorgan response. Current Problems in Cardiology, 45(8). https://doi.org/10.1016/j.cpcardiol.2020.100618

\section{MEDICINA SPORTA I VEŽBANJA U COVID-19 ERI - NAČINIMO OD TOGA DOBRU MARATONSKU TRKU}

Cilj ovog kratkog narativnog pregleda je da istraži ulogu sporta i vežbanja (SEM) u upravljanju sadašnjim i budućim pandemijama. Izbijanje koronavirusa iznenadilo je čitav svet $i$ vrlo brzo nametnulo dugoročnu borbu koja nam je promenila svaki aspekt savremenog života. Budući da je u pitanju prvenstveno zdravstvena kriza, pandemija COVID-19 nametnula je najveći pritisak na medicinsku zajednicu i nauku. Naše razumevanje novih okolnosti neprestano se upotpunjuje novim naučnim podacima, a medicinske $i$ druge struke koje se direktno bave pandemijom moraju da pruže najbolji dostupan (zasnovan na dokazima) pristup. SEM ekspertiza ima ogroman uticaj na opšte zdravlje stanovništva i njegova uloga u suočavanju sa COVID-19 i budućim pandemijama mora se da prepozna kroz nekoliko aspekata. Multidisciplinarni, preventivno orijentisani i strukturirani pristup SEM-u može da bude presudan u zdravstvenim promenama zajednice.

Ključne reči: COVID-19, fizička aktivnost, zdravlje, prevencija 